Jurnal Civic Education, Vol. 1 No. 1 Juni 2017

\title{
DISIPLIN PEGAWAI ADMINISTRASI FIS UNIMA
}

\author{
Yoseph D. A. Santie \\ Jurusan PPKn FIS UNIMA \\ E-Mail: yosh_sant@yahoo.com
}

\begin{abstract}
Abstrak
Masalah dalam penelitian ini adalah: Disiplin Pegawai Administrasi Fakultas Ilmu Sosial Universitas Negeri Manado, adapun fokus penelitian ini melihat disiplin sebagai salah satu aspek yang sangat penting dalam sistem kerja yang harus diperhatikan oleh setiap lembaga atau organisasi. Disiplin merupakan suatu proses atau pengendalian keinginan, dorongan, atau kepentingan demi tujuan atau cita-cita yang telah ditetapkan. Disiplin mempengaruhi hasil kerja pegawai, dan hal ini disebabkan oleh kemampuan seorang pegawai bekerja secara optimal dan tentunya dikendalikan oleh pemimpin yang mampu mengelola organisasi yang dipimpinnya secuai aturan yang berlaku. Disiplin kerja pegawai FIS Unima disinyalir disebabkan oleh beragam faktor, antara lain faktor individu, sistem kerja, budaya atau etos kerja.

Dalam penelitian ini, dilakukan observasi kepada para pegawai administrasi di lingkungan FIS Unima. Selanjutnya disebarkan kuesioner berisis variabel disiplin pegawai. Sampel yang ditetapkan sebanyak 21 responden. Jawaban dari kuesioner akan membantu mereduksi masalah penelitian, selanjutnya diadakan wawancara untuk mendapatlan informasi yang lebih mendalam. Hasi wawancara dan hasil kuesioner digunakan untuk melakukan interpretasi terhadap data dan dibuat pembahasan serta kesimpulan.

Hasil penelitian menggambarkan bahwa disiplin pegawai administrasi FIS Unima, belum optimal karena ada faktor-faktor yang menghambat, yaitu faktor individu seperti masalah keluarga, masalah kepribadian. Faktor sistem kerja seperti belum adanya SOP di lingkungan kerja, belum bekerja sesuai tugas pokok dan fungsi karena ketrampilan yang dimiliki. Faktor budaya atau etos kerja seperti bekerja tidak tuntas dan tidak optimal.
\end{abstract}

Kata Kunci: Disilpin, Pegawai Administrasi PNS 


\section{A. Pendahuluan}

Menurut Peraturan Pemerintah No. 53 Tahun 2010 tentang Disiplin Pegawai Negeri Sipil, diatur tentang ketentuan-ketentuan mengenai kewajiban, larangan, hukuman disiplin, tingkat dan jenis hukuman disiplin, pelanggaran dan jenis hukuman disiplin pejabat yang berwenang menghukum, berlakunya keputusan hukuman disiplin. Dengan adanya peraturan di atas, maka secara otomatis seorang pegawai negeri mampu mengapresiasi dirinya dalam setiap pekerjaannya yang menjadi tugas pokok dan fungsinya.

Seorang pegawai negeri sipil merupakan penyelenggara pemerintah dan pembangunan, sehingga dibuatkan sistem pembinaan dan penetapan gaji serta kepangkatan. Untuk mencapai tujuan kerja tersebut, maka unsur yang sangat vital antaranya disiplin kerja. Agar tercapainya disiplin kerja yang tinggi pada pegawai negeri, maka diperlukan suatu konsistensi aturan yang telah ditetapkan yang dipimpin oleh atasan.

Adapun disiplin kerja adalah suatu hal yang sangat utama dalam sistem kerja, dimana hal keberadaannya harus menjadi perhatian atasan atau pimpinan. Disiplin merupakan suatu proses atau pengendalian keinginan. Dorongan atau kepentingan demi mencapai tujuan atau cita-cita yang sudah ditetapkan. Apabila disiplin dapat dilaksanakan dengan baik serta tidak menunda waktu, maka masalah kinerja tida dibiarkan menjadi lebih parah sehingga masalah dapat diatasi dengan mudah.

Salah satu permasalahan yang dihadapi pleh pegawai negeri saat ini adalah masih rendahnya kinerja yang dimiliki oleh pegawai, yang mengakibatkan terhambatnya tujuan yang diinginkan. Dalam melaksanakan pekerjaannya seorang pegawai negeri diharapkan dapat mencapai hasil kerja yang maksimal dan berkualitas sehingga dapat meningkatkan tugas dan tanggungjawab di dalam organisasi.

Disiplin kerja mempengaruhi hasil kerja pegawai negeri, dan hal itu disebabkan oleh kemampuan seorang pegawai negeri bekerja secara maksilal dan tentunya dikendalikan oleh pemimpim yang mampu mengelola organisasi yang dipimpinnya sesuai aturan yang berlaku.
Disiplin kerja seorang pegawai neger di lingkungan FIS Unima disinylair disebabkan oleh beragam faktor, yaitu faktor individu (pribadi), sistem kerja atau budaya organisasi, budaya atau etos kerja, dengan demikian secara konseptual faktor-faktor yang memperlihatkan masih kurangnya disiplin kerja pegawai negeri dalam melakukan tugas dan pekerjaannnya disebabkan oleh faktor sosial ekonomi,faktor psikologis, antropologis dan politik.

Masalah tersebut di atas yang melatarbelakangi sehingga disiplin pegawai administrasi FIS Unima masih rendah dianggap sangat urgen sehingga diperlukan sebuah penelitian untuk mencari solusi, sehingga apa yang dicanangkan tahun 2014s sebagai tahun kinerja untuk pegawai negeri sipil khususnya di lingkungan Universitas Negeri Manado dapat terwujud, semoga.

Masalah dalam penelitian adalah: Faktorfaktor apakah yang menyebabkan masih rendahnya disiplin kerja pegawai administrasi di FIS Unima?

\section{B. Kajian Teori \\ 1. Konsep Disiplin}

Disiplin merupakan perasaan taat dan patuh terhadap nilai-nilai yang dipercaya termasuk melakukan pekerjaan tertentu yang menjadi tanggung jawabnya. Pendisiplinan adalah usaha usaha untuk menanamkan nilai ataupun pemaksaan agar subjek memiliki kemampuan untuk menaati sebuah peraturan. Pendisiplinan bisa jadi menjadi istilah pengganti untuk hukuman ataupun instrumen hukuman dimana hal ini bisa dilakukan pada diri sendiri ataupun pada orang lain.

Disiplin diri merujuk pada pelatihan yang didapatkan seseorang untuk memenuhi tugas tertentu atau untuk mengadopsi pola perilaku tertentu, walaupun orang tersebut lebih senang melakukan hal yang lain. Sebagai contoh, seseorang mungkin saja tidak melakukan sesuatu yang menurutnya memuaskan dan menyenangkan dengan membelanjakan uangnya untuk sesuatu yang ia inginkan dan menyumbangkan uang tersebut kepada organisasi amal dengan pikiran bahwa hal tersebut lebih penting. Secara etimologi disiplin berasal dari bahasa Latin "disibel" yang berarti 
Pengikut. Seiring dengan perkembangan zaman, kata tersebut mengalami perubahan menjadi "disipline" yang artinya kepatuhan atau yang menyangkut tata tertib. Disiplin memerlukan integritas emosi dalam mewujudakan keadaan. disiplin diri dapat bermula pada suatu hal yang kecil, contoh : bagi pelajar yang mampu membagi waktu belajar, membagi waktu beribadah sehingga tak menimbulkan suatu pertabrakan kegiatan pada waktu yang sama.

\section{Disiplin Pegawai Negeri Sipil Menurut PP No. 53 Tahun 2010}

Menurut Hasibuan (1997:193), disiplin adalah kesadaran dan kesediaan seseorang menaati semua peraturan dan norma-norma sosial yang berlaku. Kesadaran adalah sikap seseorang yang secara sukarela menaati semua peraturan dan sadar akan tugas dan tanggungjawabnya.

Selanjutnya menurut kamus umum bahasa Indonesia (2000:91) bahwa disiplin adalah kepatuhan dan ketaatan terhadap peraturan tata tertib, sedangkan menurut Sinungan (2006:145) mengemukakan bahwa disiplin adalah sebagai sikap mental yang tercermin dalam perbuatan atau tingkah laku perorangan, kelompok atau masyarakat berupa ketaatan terhadap peraturan atau ketentuan yang ditetapkan oleh pemerintah berupa etika, norma dan kaidah yang berlaku dalam masyarakat untuj tujuan tertentu.

Adapun pengertian disiplin dapat diartikan bilamana seorang PNS selalu datang ke kantor dan pulang dari kantor tepat pada waktunya, mematuhi semua aturan dan norma-norma yang berlaku di kantor di mana ia bekerja. Disiplin merupakan fungsi operatif, karena semakin baik disiplin pegawai, maka akan semakin baik pula prestasi kerja yang dicapai.

Menurut Peraturan Pemerintah No. 53 Tahun 2010, tentang disiplin pegawai negeri sipil, maka seorang pegawai negeri memiliki kewajiban sebagai berikut:

1. Mengucapkan sumpah dan janji PNS

2. Mengucapkan sumpah dan janji jabatan

3. Setia dan taat sepenuhnya kepada Pancasila dan UUD 1945 serta Pemerintah

4. Menaati segala peraturan per-UndangUndangan
5. Melaksanakan tugas kedinasan yang dipercayakan kepada PNS dengan penuh pengabdian, kesadaran dan tanggungjawab

6. Bekerja dengan jujur, tertib, cermat, dan bersemangat untuk kepentingan negara

7. Masuk kerja dan menaati ketentuan jam kerja Sedangkan menurut Peraturan Pemerintah N0. 53 Tahun 2010 Pasal 4, maka seorang PNS memiliki larangan sebagai berikut:

1. Menyalahgunakan wewenang

2. Menjadi perantara untuk mendapatkan keuntungan pribadi dan/atau orang lain dengan menggunakan kewenangan orang lain

3. Tanpa ijin pemerintah menjadi pegawai atau bekerja untuk negara lain dan/atau lembaga atau organisasi internasional

4. Bertindak sewenang-wenang terhadap bawahannya

5. Memberikan dukungan kepada calon kepala daerah/wakil kepala daerah, dengan cara:

a. Terlibat dalam kegiatan kampanye untuk mendukung calaon kepala daerah/wakil kepala daerah

b. Menggunakan fasilitas yang terkait dengan jabatan dalam kegiatan kampanye

c. Membuat keputusan dan/atau tindakan yang menguntungkan atau merugikan salah satu pasangan calon selama masa kampanye

d. Mengadakan kegiatan yang mengarah kepada keberpihakan tehadap pasangan calon yang menjadi peserta pemilu sebelum, selama dan sesudah masa kampanye, meliputi: pertemuan, ajakan, himbauan, seruan, atau pemberian barang kepada PNS dalam lingkungan unit kerjanya, anggota keluarga dan masyarakat.

e. Tingkat dan Jenis Hukuman Disiplin (pasal 7) yaitu:

a. Jenis hukuman disiplin ringan berupa: teguran lisan, teguran tertulis, pernyataan tidak puas secara tertulis

b. Jenis hukuman disiplin sedang berupa: penundaan kenaikan gaji berkala selama 1 (satu) tahun, penundaan kenaikan pangkat selama 1 (satu) tahun, penurunan pangkat setingkat lebih rendah selama 1 (satu) tahun. 
c. Jenis hukuman disiplin berat berupa: penurunan pangkat lebih rendah selama 3 (tiga) tahun, pemindahan dalam rangka penurunan jabatan setingkat lebih rendah, pembebasan dari jabatan, pemberhentian dengan hormat tidak atas permintaan sendiri sebagai PNS, pembehentian tidak dengan hormat sebagai PNS.

Selanjutnya menurut Budi Setiawan dan Waridin dalam Mohammad (2005) terdapat lima faktor dalam penelitian disiplin kerja terhadap memberian layanan kepada masyarakat, yaitu:

1. Kualitas disiplin kerja, yaitu datang dan pulang tepat waktu

2. Kualitas pekerjaan meliputi volume keluaran dan kontribusi

3. Kompensasi yang diperlukan meliputi saran, arahan dan perbaikan

4. Lokasi tempat kerja atau tempat tinggal

5. Konservasi meliputi penghormatan terhadap aturan dengan keberanian untuk selalu melakukan pencegahan terjadinya tindakan yang bertentangan dengan aturan.

Adapun perspektif yang menyangkut disiplin kerja menurut Rivai (2004) adalah:

1. Disiplin retributif, yaitu berusaha menghukum orang yang berbuat salah

2. Disiplin korektif, yaitu berusaha membantu karyawan yang mengkoreksi perilakunya yang tidak tepat

3. perspektif hak-hak individu yaitu berusaha melindungi hak-hak individu selama tindakan tindakan disipliner

4. Perspektif utilitarian, berfokus pada penggunaan disiplin.

Selanjutnya menurut Rivai terdapat 3 konsep dalam pelaksanaan tindakan disiplin, yaitu:

1. Aturan tungku panas, yaitu pendekatan untuk melaksanakan disipliner

2. Tindakan disiplin progresif, yaitu untuk memastikan bahwa terdapat hukum minimal yang tepat terhadap setiap pelanggaran

3. Tindakan disiplin positif yaitu dalam banyak situasi, hukuman tindakan memotivasi karyawan mengubah suatu perilaku.
Berdasarkan pada pengertian-pengertian di atas, maka tolok ukur pengertian disiplin pegawai adalah:

1. Kepatuhan terhadap jam-jam kerja

2. Kepatuhan terhadap instruksi dari atasan, serta pada peraturan dan tata tertib yang berlaku

3. Berpakaian yang baik pada tempat kerja dan menggunakan tanda pengenal instansi

4. Menggunakan dan memelihara bahan dan alat kantor dengan penuh tanggungjawab

5. Bekerja dengan cara-cara yang telah ditentukan.

\section{Metode Penelitian}

Metode yang digunakan dalam Penelitian ini adalah metode penelitian deskriptif kualitatif, yaitu mengkaji masalah disiplin pegawai FIS Unima dengan mendeskripsikan secara kualitatif data dan fakta dari hasil pengamatan peneliti, dan hal ini sejalan dengan pendapat Nawawi (1992) yang mengemukakan bahwa penelitian deskriptif adalah prosedur pemecahan masalah yang diselidiki dengan jalan menggambarkan keadaan atau peristiwa pada saat sekarang didasarkan pada fakta-fakta tertentu.

Populasi dalam penelitian ini adalah seluruh pegawai administrasi yang berada di lingkungan FIS Unima, dengan jumlah 21 orang pegawai, sedangkan sampel dalam penelitian ini adalah keseluruhan dari populasi dengan jumlah 21 orang pegawai.

Data dikumpulkan dalam penelitian ini adalah lewat pengamatan, wawancara, kuesioner dan kepustakaan. Data yang dipeeroleh kemudian dianalisis dengan menggunakan teknik analisis deskriptif kualitatif, yaitu pertama data dikelompokkan menusut jenisnya, kedua data dihubung-hubungkan antara masalah yang satu dengan yang lain, kemudian data diperiksa, diteliti kebenarannya, ketiga data dideskripsikan dalam bentuk uraian-uraian sehingga dapat memberikan gambaran yang jelas, bermakna sesuai dengan tujuan penelitian. Keempat data yang dideskripsikan dibuat interpretasi data dan kemudian ditarik kesimpulan.

Lokasi penelitian adalah di kampus FIS Unima Tondano, dan yang menjadi objek 
penelitian adalah bagi para pegawai administrasi di FIS Unima.

\section{Pembahasan}

Berdasarkan data hasil analisis dan interpretasi data di atas maka disiplin Pegawai administrasi di FIS Unima belum sesuai dengan harapan dan keinginan Peraturan Pemerintah No. 53 Tahun 2010 tentang Disiplin PNS. Adapun jiwa dan semangat Peraturan Pemerintah tersebut seyogyanya adalah membangun kesadaran untuk bersikap secara sukarela menaati semua peraturan dan sadar akan tugas dan tanggungjawab sebagai abdi negara dan abdi masyarakat.

Sebagai seorang abdi negara dan abdi masyarakat yang telah diangkat sumpah jabatannya selalu patuh pada tugas pokok dan fungsinya menjadi insan yang mengerjakan semua pekerjaannya dengan baik dan tepat waktu. Seorang PNS yang disiplin dalam bekerja, maka secara otomatis akan berprestasi pula dalam tugas pekerjaannya.

Hal tersebut di atas sejalan dengan pendapat dari Hasibuan (1997) yang menyatakan bahwa seorang yang sadar dan rela bersedia menaati semua aturan dan normanorma sosial yang berlaku maka dia disebut orang yang memiliki sikap disiplin yang baik.

Disiplin yang baik dari seorang PNS ditunjukkan dari konsistensinya ia bekerja dengan aturan yang ada dan perencanaan pekerjaannya yang terukur dan produktif, bekerja dengan penuh kejujuran, tertib dan cermat serta bersemangat untuk kepentingan lembaga di mana ia bekerja serta kepentingan umum.

Seorang PNS yang diharapkan memiliki sikap disiplin dalam bekerja apabila ia masuk dan pulang bekerja sesuai aturan yang ditetapkan, juga selalu menghindar dari perbuatan-perbuatan tercela dan tidak bersikap anti sosial serta tidak melakukan pelanggaran.

Seluruh harapan-harapan di atas belum tergambar secara optimal dalam atmosfir kerja di lingkungan FIS Unima, selain hanya rutinitas semata dan tidak mencerminkan suatu instansi yang kompetitif dan penuh ethos kerja yang baik.
Adapun suasana disiplin kerja para staf administrasi di FIS Unima belum sepenuhnya memiliki kualitas disiplin kerja, yaitu datang dan bekerja serta pulang kerja dengan tepat waktu, juga volume keluaran dan kontribusi atas pekerjaan yang belum optimal.

Hal tersebut di atas disinyalir disebabkan oleh masih lemahnya motivasi kerja serta kurangnya rasa memiliki dari staf pegawai administrasi dalam bekerja, serta didukung oleh gaya kepemimpinan atasan yang tidak transformatif. Membiarkan para pegawai mengatur kerjanya sendiri-sendiri tanpa adanya pengawasan atasan langsung serta tidak adanya kontrol dan evaluasi terhadap pekerjaan para pegawai. Faktor lain yang menyebabkan lemahnya disiplin pegawai administrasi bekerja di FIS Unima ditenggarai antara lain karena jarak rempat tinggal dan tempat bekerja cukup jauh, kurang tegasnya pimpinan memberikan sanksi kepada pegawai yang melanggar aturan, serta lemahnya penghormatan tehadap aturan oleh pimpinan dan juga oleh staf pegawai.

\section{E. Kesimpulan}

Berdasarkan hasil penelitian dan pembahasan tersebut di atas, maka dapat disimpulkan bahwa:

1. Disiplin pegawai FIS Unima belum optimal, karena kesadaran akan tanggungjawab atas pekerjaan yang diemban sesuai PP No. 53 Tahun 2010 tentang disiplin PNS belum dipahami secara maksimal.

2. Sanksi yang diberikan oleh atasan masih belum tegas

3. Belum adanya penghargaan yang diberikan kepada pegawai yang berprestasi

4. Tidak adanya perencanaan kerja yang sesuai dengan tugas pokok dan fungsi masingmasing pegawai

5. Monitoring dan evaluasi terhadap pegawai yang belum dilaksanakan oleh atasan

6. Kompetensi yang dimiliki oleh pegawai masih belum memadai 


\section{DAFTAR PUSTAKA}

Rivai, dkk. 2004. Performance Appraisal Sistem Yang Tepat Untuk Menilai Kinerja Karyawan Dan Meningkatkan Daya Saing Peerusahaan. PT RajaGrafindo Persada, Jakarta.

Sinungan, Uma, 2006. Research Methode For Bussiness: Metodologi Penelitian Untuk Bisnis. Salemba Empat, Jakarta.

Simamora, 2002. Dampak Motivasi Karyawan Pada Hubungan Antara Gaya Kepemimpinan Dengan Kinerja Karyawan Perusahaan Bisnis. Empirika Vol. 15 No. 2

Widodo, Joko. 2006. Membangun Birokrasi Berbasis Kinerja. Bayumedia Publishing, Jakarta.

Peraturan Pemerintah Nomor 53 Tahun 2010 Tentang Peraturan Disiplin PNS

http://id.wikipedia.org/wiki/kinerja

http://reviewtesis.blogspot.com/2008/02/14/pen garuh pengawasan dan disiplin.hmti http://mick182.

Blogspot.com/2008/10/mengatasi-perilakudisiplin-pengawas.htmi 